\title{
Restoring Serotonergic Homeostasis in the Lateral Hypothalamus Rescues Sleep Disturbances Induced by Early-Life Obesity
}

\author{
Mary Gazea, ${ }^{1}$ Alexandre V. Patchev, ${ }^{1}$ Elmira Anderzhanova, ${ }^{1,2}{ }^{-}$Este Leidmaa, ${ }^{1}$ Anna Pissioti, ${ }^{1}$ Cornelia Flachskamm, ${ }^{1}$ \\ (C) Osborne F.X. Almeida, ${ }^{1}$ and ${ }^{\circledR}$ Mayumi Kimura ${ }^{1}$ \\ ${ }^{1}$ Max Planck Institute of Psychiatry, 80804 Munich, Germany, and ${ }^{2}$ Federal State Budgetary Institution Zakusov Institute of Pharmacology, 125315 \\ Moscow, Russia
}

Early-life obesity predisposes to obesity in adulthood, a condition with broad medical implications including sleep disorders, which can exacerbate metabolic disturbances and disrupt cognitive and affective behaviors. In this study, we examined the long-term impact of transient peripubertal diet-induced obesity (ppDI0, induced between 4 and 10 weeks of age) on sleep-wake behavior in male mice. EEG and EMG recordings revealed that ppDIO increases sleep during the active phase but reduces resting-phase sleep quality. This impaired sleep phenotype persisted for up to 1 year, although animals were returned to a non-obesiogenic diet from postnatal week 11 onwards. To better understand the mechanisms responsible for the ppDIO-induced alterations in sleep, we focused on the lateral hypothalamus (LH). Mice exposed to ppDIO did not show altered mRNA expression levels of orexin and melanin-concentrating hormone, two peptides that are important for sleep-wake behavior and food intake. Conversely, the LH of ppDIO-exposed mice had reduced contents of serotonin (5-hydroxytryptamine, 5-HT), a neurotransmitter involved in both sleep-wake and satiety regulation. Interestingly, an acute peripheral injection of the satiety-signaling peptide YY 3-36 increased 5-HT turnover in the LH and ameliorated the ppDIO-induced sleep disturbances, suggesting the therapeutic potential of this peptide. These findings provide new insights into how sleep-wake behavior is programmed during early life and how peripheral and central signals are integrated to coordinate sleep.

Key words: mice; obesity; puberty; PYY; serotonin; sleep disorders

Significance Statement

Adult physiology and behavior are strongly influenced by dynamic reorganization of the brain during puberty. The present work shows that obesity during puberty leads to persistently dysregulated patterns of sleep and wakefulness by blunting serotonergic signaling in the lateral hypothalamus. It also shows that pharmacological mimicry of satiety with peptide $\mathrm{YY}_{3-36}$ can reverse this neurochemical imbalance and acutely restore sleep composition. These findings add insight into how innate behaviors such as feeding and sleep are integrated and suggest a novel mechanism through which diet-induced obesity during puberty imposes its long-lasting effects on sleep-wake behavior.

\section{Introduction}

Many aspects of adult physiology and behavior, including the timing, duration, and depth of sleep, are determined by extensive reorganization of neural circuits during the peripubertal period

\footnotetext{
Received May 16, 2017; revised Sept. 13, 2017; accepted 0ct. 12, 2017.

Author contributions: M.G., A.V.P., O.F.A., and M.K. designed research; M.G., A.V.P., E.A., E.L., A.P., and C.F. performed research; M.G., E.A., and C.F. analyzed data; M.G., O.F.A., and M.K. wrote the paper.

This work was supported by a European Union-funded FP7 Integrated Project (SwitchBox; Contract 259772). We thank Stephanie Alam, Andrea Ressle, and Rainer Stoffel for technical assistance and Professor Axel Steiger for valuable comments.

The authors declare no competing financial interests.

M. Gazea's present address: Department of Neurology, Inselspital University Hospital, University of Bern, 3010 Bern, Switzerland.

A.V. Patchev's present address: GKM Gesellschaft für Therapieforschung mbH, 80336 Munich, Germany.
}

(Spear, 2000; Hagenauer and Lee, 2013; Nelson et al., 2013). Rodent studies have suggested that even mild, transient environmental perturbations during this sensitive phase exert persistent effects on health and well-being (Vendruscolo et al., 2010; Patchev et al., 2014; Iñiguez et al., 2015). Food preferences develop early in humans (Spear, 2000) and increase the propensity to become obese (Serdula et al., 1993; Spear, 2000), thereby raising the risk for acquiring serious conditions such as cardiovascular disease, type 2 diabetes, and affective and cognitive disorders (Alfaradhi

Correspondence should be addressed to Dr. Mayumi Kimura, Max Planck Institute of Psychiatry, Kraepelinstrasse 2-10,80804 Munich, Germany. E-mail: kimura@psych.mpg.de.

DOI:10.1523/JNEUROSCI.1333-17.2017

Copyright $\odot 2018$ the authors $\quad 0270-6474 / 18 / 380441-11 \$ 15.00 / 0$ 
and Ozanne, 2011; Kelsey et al., 2014; Balakumar et al., 2016). Importantly, obesity also triggers disturbed sleep-wake behavior, with poor sleep due to frequent nighttime awakening and daytime sleepiness being a common complaint in obese subjects (Vgontzas et al., 2008). It is also pertinent to note that sleep disturbances are strongly linked to impaired mood (Steiger and Kimura, 2010) and cognition (Havekes et al., 2015; Tarokh et al., 2016). The recognition of an association among sleep, metabolism, and physical and mental health has spurred considerable interest recently (Dresler et al., 2014); however, little is known regarding the mechanisms underpinning these interactions or indeed about where and when they are initiated. Obese humans and mice both display sleep disturbances (Jenkins et al., 2006; Guan et al., 2008; Perron et al., 2015). Importantly, polysomnograms of EEG and EMG activity in both species allow distinction between shallow-to-deep, nonrapid eye movement (NREM) sleep (characterized by synchronized cortical neuronal activity, reflected in high-delta-power EEG) and REM sleep (a low-conscious state despite high cortical activity) (Tobler, 1995). Moreover, quality of sleep, which often correlates negatively with obesity and aging (Vgontzas et al., 2008; Steiger and Kimura, 2010) and which is reflected in high delta power during uninterrupted NREM sleep (Borbély, 1977), can be equally well assessed in humans and rodents.

Feeding rhythms are tightly coupled to sleep-wake bouts and both behaviors occur in a circadian fashion (Challet, 2013). Sleep curtailment promotes food intake such as intermittent "snacking" and raises the risk of obesity in humans and rodents (Markwald et al., 2013; Wang et al., 2014; Chaput and Dutil, 2016). Conversely, food deprivation in rodents causes arousal and facilitates food-seeking behavior (Borbély, 1977). However, the effects of fasting are abolished by ablation of orexin neurons in the lateral hypothalamus (LH) (Yamanaka et al., 2003a), a finding consistent with recent work demonstrating that signals converging in the LH contribute to the coordination of feeding and sleepwake behavior (Bonnavion et al., 2016; Stuber and Wise, 2016). Complementary work demonstrated that neuropeptide secretion by the LH is subject to modulation by arousal- and satiety-promoting serotonergic (5-HTergic) inputs from the dorsal raphe nucleus (DR) (Yamanaka et al., 2003b; Saper et al., 2010; Ito et al., 2013; Chowdhury and Yamanaka, 2016). Together, these previous observations prompted the question of whether peripubertal obesity predisposes to impaired sleep quality in later life and, if so, how altered LH function might serve as a conduit of the effects of early life challenges to metabolic status. In addition to confirming our hypothesis that peripubertal diet-induced obesity (ppDIO) generates long-lasting impairments in sleep quality, we demonstrated that ppDIO-induced sleep disturbances are accompanied by reductions in the serotonin (5-hydroxytryptamine, 5-HT) content of the LH. Furthermore, we show that a single peripheral injection of the satiety-signaling gut peptide, peptide $\mathrm{YY}\left(\mathrm{PYY}_{3-36}\right)$, ameliorates the aberrations in sleep patterns produced by ppDIO significantly.

\section{Materials and Methods}

Animals. Male C57BL/6N mice, bred at the Max Planck Institute of Biochemistry, were obtained at $21 \mathrm{~d}$ of age and housed (4 mice/cage) under standard conditions. One group of mice (ppDIO; $n=65)$ was given ad libitum access to a high-fat diet (HFD; $4.73 \mathrm{kcal} / \mathrm{g} ;$ D12451, Research Diets) for 6 weeks (postnatal weeks 4-10). A control group of mice $(n=$ 68 ) was maintained on standard laboratory chow ( $2.85 \mathrm{kcal} / \mathrm{g}$, diet \#1324, Altromin) throughout the experiment. All procedures on animals were approved by the Government of Upper Bavaria's Commission for the Care and Use of Laboratory Animals in Germany.
Diets. Compositions of diets were as follows: the HFD used in the ppDIO paradigm from weeks $4-10(4.73 \mathrm{kcal} / \mathrm{g})$ was $45 \%$ fat, $20 \%$ protein, and 35\% carbohydrates; the standard laboratory diet fed to controls and ppDIO mice from 11 weeks of age onwords ( $2.84 \mathrm{kcal} / \mathrm{g}$ ) was $12.6 \%$ fat, $26.7 \%$ protein, and $60.7 \%$ carbohydrates.

Housing. Mice were kept on a 12:12 light/dark cycle [lights on at 08:00, Zeitgeber time (ZT) 0] under constant temperature $\left(24 \pm 1{ }^{\circ} \mathrm{C}\right)$ and relative humidity $(50 \pm 10 \%)$ in a sound-attenuated chamber. The animals were individually housed in custom-made Lucite cages (transparent Lucite walls, $35 \mathrm{~cm}$ height; replaceable, gray Lucite floor, $26 \mathrm{~cm} \times 26 \mathrm{~cm}$ ) from the time of surgeries and maintained under the same environmental conditions as before.

Surgery. Control and ppDIO mice aged 8, 22, and 50 weeks were implanted with 4 epidural EEG gold-wire electrodes under isoflurane/oxygen anesthesia. As described previously (Romanowski et al., 2010; Kumar et al., 2015), bilateral electrodes were placed on the frontal lobes (L: \pm 1.7 $\mathrm{mm}$, AP: $+1.5 \mathrm{~mm}$ from bregma) and parietal lobes (L: $\pm 3 \mathrm{~mm}$ from bregma, AP: $+1 \mathrm{~mm}$ from lambda), respectively. In addition, each mouse received two intramuscular (neck) gold-wire electrodes for EMG recordings. The lead wires of the EEG and EMG electrodes were connected to an electric swivel through a flexible tether, as described previously (Kumar et al., 2015). The first baseline EEG and EMG recordings were made after a $14 \mathrm{~d}$ postsurgical recovery period in freely behaving mice.

Sleep recording and analysis. Polysomnographic recordings were obtained using a LabVIEW-based acquisition system (National Instruments) customized for use in mice (EGErAVigilanz; SEA) (Kumar et al., 2015). EEG and EMG signals were amplified $(10,000 \times)$ and both filtered EEGs $(0.25-64 \mathrm{~Hz})$ and EMGs $(175-1000 \mathrm{~Hz}$, root mean square rectified) were digitized using a high-speed analog-to-digital converter (NIUSB-6343-X-series; National Instruments) at a sampling rate of $128 \mathrm{~Hz}$.

Sleep data were processed by fast Fourier transform algorithmic analysis and semiautomatic classification of particular sleep-wake vigilance states was achieved using the LabVIEW-based acquisition system (National Instruments). As described previously (Kimura et al., 2010), vigilance states were defined from polygraphic traces in consecutive $4 \mathrm{~s}$ epochs as wakefulness, REM sleep, and NREM sleep; these states were confirmed by visual inspection of the somnograms. Images of dynamic changes in spectral power densities were produced by averaging absolute spectrum data encompassing all vigilance states from individual animals (30 consecutive $4 \mathrm{~s}$ epochs, i.e., per 2 min duration); 3D plots were subsequently created using Origin 8 software (OriginLab), as described previously (Jakubcakova et al., 2011). Slow-wave activity (SWA) was calculated from the absolute power of the frequency range between 0.5 and $4 \mathrm{~Hz}$ during NREM sleep per $0.25 \mathrm{~Hz}$ bins and normalized to the individually averaged total EEG power of all vigilance states. Epochs containing artifacts were eliminated from the power spectral analysis. Sleep architecture was analyzed by quantifying the number of transitions from WAKE to NREMS, NREMS to REMS, REMS to WAKE, and NREMS to WAKE in $6 \mathrm{~h}$ bins.

Brain tissue collection and processing. Mice were deeply anesthetized (isoflurane) and killed by decapitation at ZT 8 or ZT 13 ( \pm 15 min) after $\mathrm{PYY}_{3-36} /$ vehicle injections. Brains were carefully removed from the skull, snap frozen in isopentane/dry ice, and stored at $-80^{\circ} \mathrm{C}$ until further processing.

For in situ hybridization histochemistry (see below), $10-\mu \mathrm{m}$-thick coronal sections from areas containing the $\mathrm{LH}$ were cryo-cut at $-20^{\circ} \mathrm{C}$ and mounted on SuperFrost Plus slides (Menzel).

For neurotransmitter and neuropeptide measurements (see below), cylindrical cubes $\left(0.5 \mathrm{~mm}^{3}\right.$ tissue punches) containing the $\mathrm{LH}$ or DR were obtained as described previously (Palkovits, 1973) (coordinates for LH: AP $-1.3 \mathrm{~mm}, \mathrm{DV}-4.8 \mathrm{~mm}, \mathrm{~L} \pm 1.0 \mathrm{~mm}$ from bregma, and for DR: AP $-4.3 \mathrm{~mm}, \mathrm{DV}-2.8 \mathrm{~mm}, \mathrm{~L} \pm 0.5 \mathrm{~mm}$ from bregma).

In situ hybridization histochemistry. Ten-micrometer cryo-cut sections of brains obtained from mice at ZT 8 were hybridized with ${ }^{35} \mathrm{~S}$-dATPlabeled oligonucleotide probes for orexin (5'AGCAGCGTCACGGCG GCCCAGGGAACCTTTGTAG), $M C H$ (5'CAACATGGTCGGTAGACT CTTCCCAGCATACACCTGAGCATGTCAA), and GAD67 (5' CAGTCA ACCAGGATCTGCTCCAGAGACTCGGGGTGGTCAGACAGCTCCA), as described previously (Patchev et al., 2007). Autoradiograms were gen- 
erated by exposure to chemiluminescent film (BioMax MR; Kodak) and digitized; signal intensity (relative mRNA levels) was quantified by computer-assisted optical densitometry (ImageJ) against a ${ }^{14} \mathrm{C}$ reference (range: 0-35 nCi/mg; ARC 0146, American Radiolabeled Chemicals). Signal intensities are given as nanocuries per milligram.

Monoamine assay. Monoamines were extracted from the LH and DR using $0.1 \mathrm{M}$ perchloric acid (1:20 for $\mathrm{LH}$ and 1:10 for DR). The extracts were assayed for 5-HT, dopamine (DA), 3,4-dihydroxyphenylacetic acid (DOPAC), homovanillic acid (HVA), 3-methoxytyramine (3-MT), and 5-hydroxyindoleacetic acid (5-HIAA) using reverse-phase high-performance liquid chromatography (RP-HPLC) with electrochemical detection (UltiMate3000/CoulochemIII; Thermo Fisher) using citratephosphate buffer (containing $8.5 \%$ acetonitrile, $\mathrm{pH} 3$ ) as the mobile phase, as described previously (Anderzhanova et al., 2013). Monoamines were separated on an analytical column $(\mathrm{C} 18,150 \mathrm{~mm} \times 3 \mathrm{~mm}, 3 \mu \mathrm{m}$; Triart, YMC Europe) at a flow rate of $0.5 \mathrm{ml} / \mathrm{min}$ and detected at -175 $\mathrm{mV}$. The detection limit for all compounds of interest was between 0.032 and $0.050 \mathrm{~nm}$. Peak areas were used to calculate monoamine concentrations by reference to an external standard curve. Monoamine tissue contents are reported as micromoles per milligram of protein (the protein concentration of extracts was determined by the Lowry assay method; Lowry et al., 1951). To evaluate the acute effects of PYY ${ }_{3-36}$ treatment, 5-HT turnover was calculated as the ratio between the tissue levels of 5-HT and its major metabolite, 5-HIAA (Le Moal and Simon, 1991).

Radioimmunoassay (RIA). An RIA kit (Phoenix Pharmaceuticals) was used to determine orexin A concentrations in bilateral perchloric acidextracted LH tissue extracts (see "Monoamine assay" section above). The limit of detection of the RIA was $10 \mathrm{pg} / \mathrm{ml}$ and interassay and intraassay coefficients of variation were $<15 \%$.

Peptide $Y Y_{3-36}$ administration. Subgroups of control and ppDIO mice were given a single intraperitoneal injection of either $\mathrm{PYY}_{3-36}(\mathrm{H}-6042$; Bachem) or vehicle $(0.9 \% \mathrm{NaCl})$ when 10 or 52 weeks of age. Previous studies by others (Akanmu et al., 2006) and our own pilot studies showed that the dose chosen $(60 \mu \mathrm{g} / \mathrm{kg})$ reduces food ingestion and induces NREM sleep in naive adult rodents. Here, food intake was monitored at 1,3 , and $24 \mathrm{~h}$ after injection and sleep EEG/EMG recordings were made for $24 \mathrm{~h}$ after injection. Brain punches obtained from a separate group of control and ppDIO mice treated with vehicle or $\mathrm{PYY}_{3-36}$ for $1 \mathrm{~h}$ were used for determining neurotransmitter contents by RP-HPLC (see above).

Experimental design and statistical analysis. Primarily, six individual groups were set for studying and comparing the effects of transient HFD exposure during puberty (ppDIO vs control group) on sleep parameters at three different time spans (10,24, and 52 weeks of age). Weekly changes in body weight (BW; in grams), hourly changes in $24 \mathrm{~h}$ sleep (percentage per hour), the amount of time spent in sleep during ZT 13-18 (percentage per $6 \mathrm{~h}$ ), and differences in SWA during baseline (in percentage of total power) and after sleep deprivation (relative changes from baseline SWA in percentage) were analyzed by two-way ANOVA, with the between factors age and diet. A multivariate ANOVA (MANOVA) was applied to evaluate the effects of age, diet (both between factors), and time (within factor) on vigilance transitions (counts) in $6 \mathrm{~h}$ bins. Neurochemical parameters such as orexin mRNA expression or protein levels and tissue neurotransmitter contents, which might have been affected by the ppDIO paradigm, were analyzed between only two age groups (10 and 52 weeks) using two-way ANOVA, with the between factors age and diet. To explore a therapeutic potentiality, the effects of peripherally administered $\mathrm{PYY}_{3-36}$ on food intake and sleep amount were compared with the counterpart group that received vehicle at 10 and 52 weeks of age by two-way ANOVA ( $\mathrm{PYY}_{3-36}$ vs vehicle treatment served as within factors, and diet or age as between factors). The effects of $\mathrm{PYY}_{3-36}$ versus vehicle on neurotransmitter turnover were tested only in 10-week-old groups and analyzed by two-way ANOVA; the included factors were diet (between) and treatment (within). The above ANOVA and MANOVA analyses were followed by Sidak's multiple-comparisons test and Bonferroni post hoc comparisons, respectively; a value of $p<0.05$ was considered significant. To perform these statistical comparisons, GraphPad Prism version 6.01 software and SPSS version 18 software were used. All data are shown as mean \pm SEM.

\section{Results}

Transient exposure to an obesogenic diet during puberty results in persistent sleep impairments

The ppDIO paradigm (transient exposure of mice to an obesogenic HFD between the ages of 4 and 10 weeks) significantly increased BW (Fig. $1 A ; p<0.01$, Sidak's post hoc test; weight gain between 4 and 10 weeks of age in control mice: $15.49 \pm 0.35 \mathrm{~g}$ vs $18.04 \pm 2.28 \mathrm{~g}$ in ppDIO animals). Reinstatement of the standard, nonobesogenic diet resulted in an initial loss (weeks 11-14) of BW in ppDIO mice, but this was followed by consistently higher BWs that were maintained for up to 1 year (Fig. $1 A$; diet effect: $F_{(1,29)}=7.201, p<0.05$, age effect: $F_{(47,1363)}=485.4, p<$ $0.01,2$-way ANOVA). These BW profiles were matched by significant differences in BW-adjusted energy intake between ppDIO and control mice, with the factors age and diet making significant contributions (Fig. $1 A$, inset; diet effect: $F_{(1,6)}=8.932$, $p<0.05$, age effect: $F_{(46,276)}=447.2, p<0.01$, diet-age interaction: $F_{(46,276)}=17.91, p<0.01,2$-way ANOVA). Whereas the obesogenic diet led to an expected increase in caloric intake $(p<$ 0.01 , Sidak's post hoc test) because of its high energy density and known hedonic properties, ppDIO mice showed an initial decrease in energy consumption when returned to standard diet (Fig. $1 A$, inset; $p<0.01$, weeks $11-14$, Sidak's post hoc test, ppDIO vs control mice).

Next, using standardized EEG/EMG recording-based classification of vigilance states, we observed typical circadian sleepwake profiles in control and ppDIO mice at between 10 and 52 weeks of age (Fig. 1B). However, 10-week-old ppDIO mice showed an increase in NREM sleep time between ZT 13 and 18 when control mice were displaying high levels of activity (wakefulness; $p<0.01$, Sidak's post hoc test, NREM sleep in 10-week-old controls: $10.8 \pm 1.51 \%$ vs in ppDIO mice: $21.0 \pm 1.43 \%$ ); the aberrant NREM sleep in ppDIO animals was particularly conspicuous at ZT 17 (Fig. 1B, top left; $C$, left; $p<0.05$, Sidak's post hoc test). A similar trend for increased NREM sleep during ZT 13-18 was observed in 24-week-old ppDIO (Fig. $1 B$, middle left; $C$, left; NREM sleep in 24-week-old controls: $18.3 \pm 2.47 \%$ vs ppDIO mice: $24.1 \pm 2.75 \%$ ). At 52 weeks of age, NREM sleep duration between ZT 13 and ZT 18 was significantly greater in the ppDIO group than in control mice (Fig. $1 B$, bottom left; $C$, left; $p<0.05$, Sidak's post hoc test; NREM sleep in controls: $20.8 \pm 2.18 \%$ vs ppDIO mice: $28.7 \pm 2.77 \%$ ). However, whereas both ppDIO and control mice displayed age-related increases in NREM sleep during ZT 13-18 (Fig. 1C, left; age effect: $F_{(2,61)}=9.53, p<0.01$, 2-way ANOVA), the ppDIO group showed consistently greater amounts of NREM sleep compared with the controls (diet effect: $F_{(1,61)}=20.40, p<0.01,2$-way ANOVA).

At 10, 24, and 52 weeks of age, control and ppDIO mice showed highly similar circadian REM sleep profiles (Fig. $1 B$, right). However, consistent with the corresponding patterns of NREM sleep, ppDIO animals spent more time in REM sleep during ZT 13-18 compared with controls (Fig. $1 C$, right; diet effect: $F_{(1,61)}=$ 7.29, $p<0.01,2$-way ANOVA; Sidak's post hoc comparisons: n.s.). Nevertheless, the REM/NREM sleep ratios did not differ between control and ppDIO mice at any of the ages studied (data not shown).

Sleep architecture, judged by the frequency of transitions between different states of vigilance, differed significantly between 10 -week-old control and ppDIO mice. Specifically, stability of sleep was poorer in the ppDIO group; in these animals, NREM sleep was frequently interrupted by bouts of wakefulness (Fig. $2 \mathrm{~A}$, top, $p<0.01$, Bonferroni post hoc comparisons). However, the 

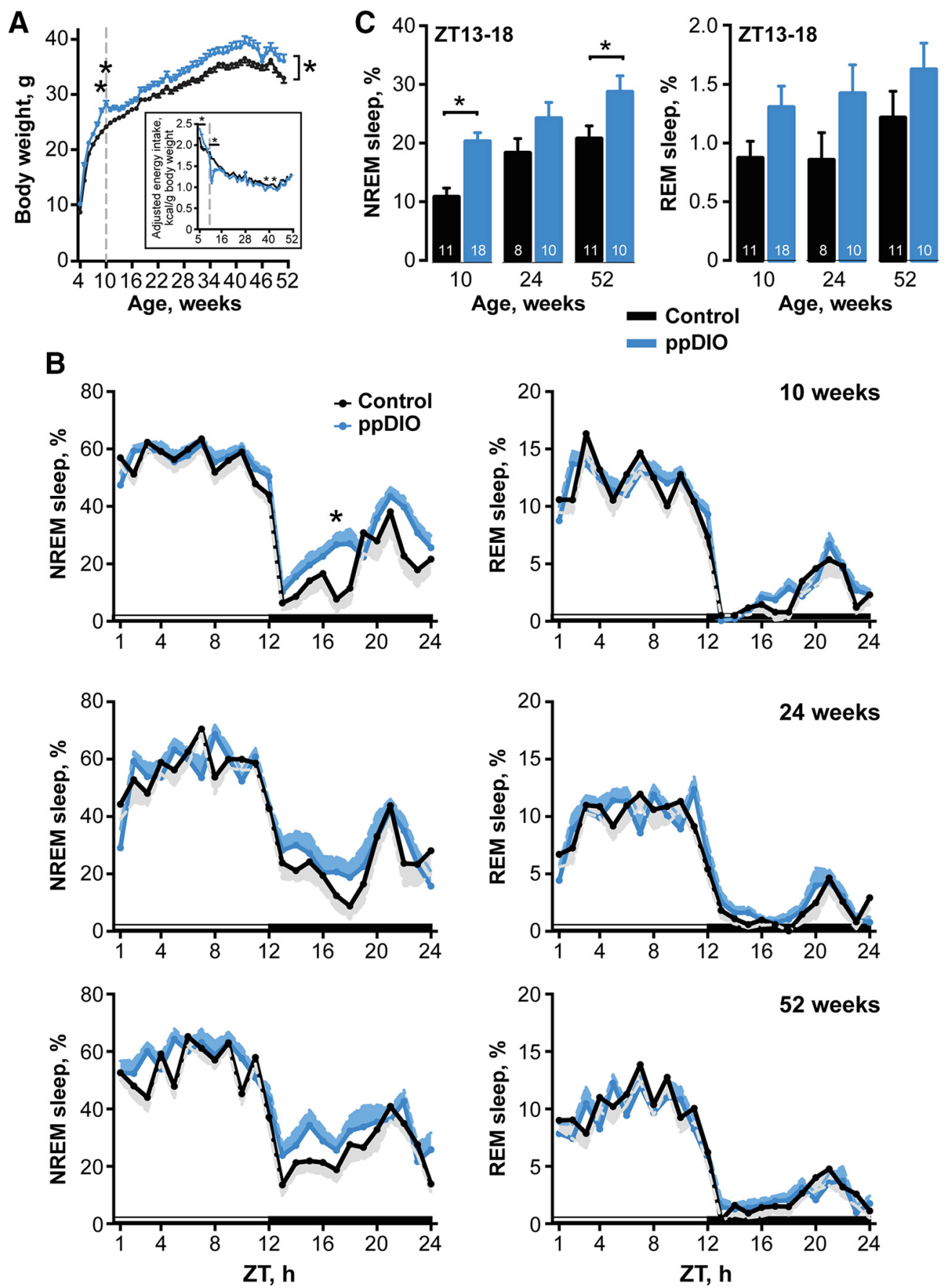

Figure 1. Peripubertal exposure to obesogenic food induces lifetime obesity and increased nocturnal sleep. $A$, BWs in ppDIO $(n=16)$ and control $(n=15)$ mice are given as mean gram per week \pm SEM. The six-week HFD exposure during peripuberty (postnatal weeks 4-10) led to significantly enhanced weight gain in ppDI0 mice compared with controls even after HFD was replaced with the standard diet $(p<0.05)$. A dashed gray line indicates the end of HFD exposure. Inset shows weekly BW-adjusted energy intake in ppDI0 and control mice, shown as mean kilocalories per gram BW \pm SEM. B, Circadian dynamics of $24 \mathrm{~h}$ NREM (left) and REM (right) sleep in ppDI0 and control mice during aging. Data points represent time spent in NREM or REM sleep per hour expressed as percentage \pm SEM. Significant differences in sleep patterns between the two groups appeared during the first half of the dark period when the active phase started $(p<0.05)$. White and black bars above the $x$-axis refer to the daily light/dark cycle. The respective numbers of animals studied under each condition are shown in corresponding bars in $C$. C, Comparison of the amount of sleep during ZT 13-18 in different age groups. Each bar represents averaged percentage time ( \pm SEM) spent in NREM (left) or REM (right) sleep between ZT 13 and 18. Time spent in NREM sleep increased significantly during aging (age effect; $p<0.01$ ) and was consistently higher in ppDI0 mice (diet effect; $p<0.01$ ). Similarly, REM sleep was elevated in ppDI0 mice (diet effect; $p<0.01)$. ${ }^{*} p<0.05$.

difference in sleep-wake architecture between control and ppDIO mice was diminished when animals were 1 year old (Fig. $2 A$, bottom); this could be ascribed to age-dependent increases in the number of NREM $\rightarrow$ WAKE and WAKE $\rightarrow$ NREM transitions in control mice (Fig. 2A, bottom, diet-age-time interaction: NREM $\rightarrow$ WAKE transitions: $F_{(1,46)}=9.266, p<0.01$; WAKE $\rightarrow$ NREM transitions: $F_{(1,46)}=9.599, p<0.01$, MANOVA). In contrast, no differences in switches from NREM $\rightarrow$ REM and REM $\rightarrow$ WAKE were found between ppDIO and control mice regardless of age (data not shown). These observations show that the disruptive effects of ppDIO on sleep continuity are greater in peripubertal versus mature mice.

Sleep demand (homeostatic sleep pressure) accumulates during periods of wakefulness and can be assessed by measurements 
A

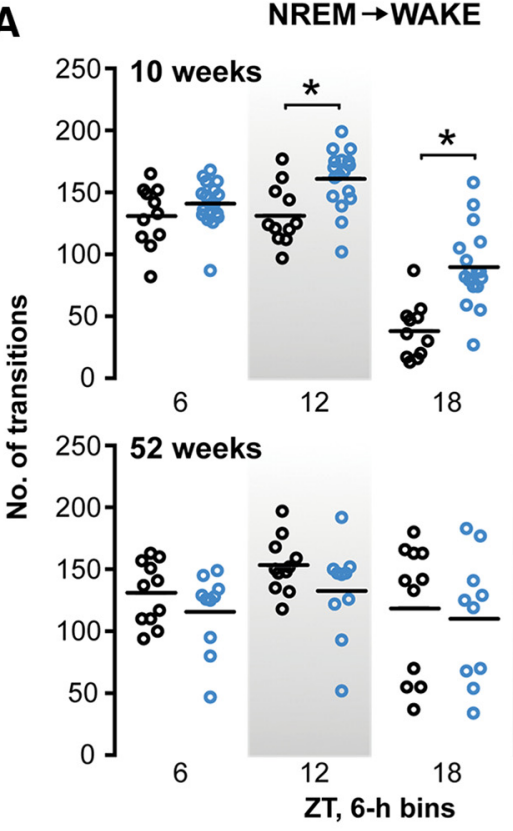

WAKE $\rightarrow$ NREM

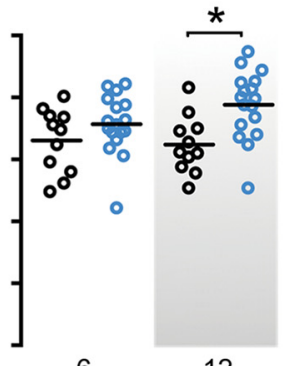

6

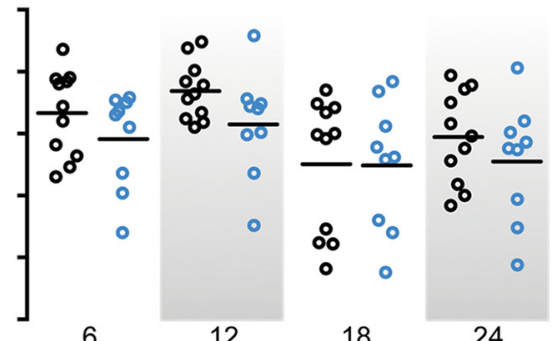

6

ZT, 6-h bins

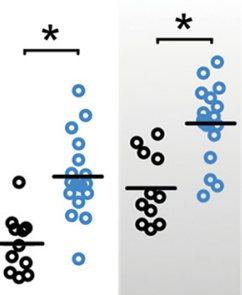

24

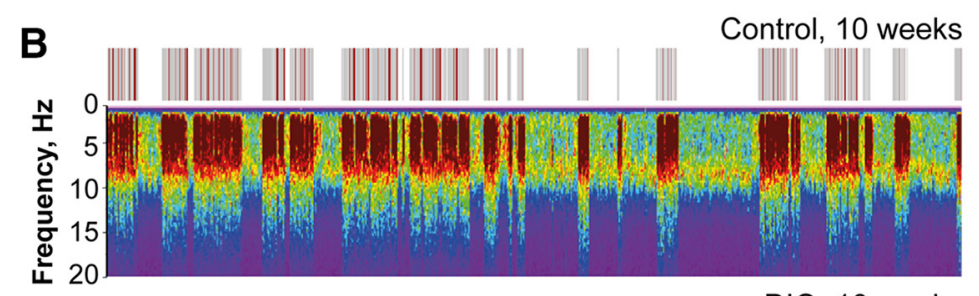

Control, 10 weeks

$$
\begin{aligned}
& \square \text { NREM sleep } \\
& - \text { REM sleep } \\
& \square \text { Wakefulness }
\end{aligned}
$$

Low

ppDIO, 10 weeks
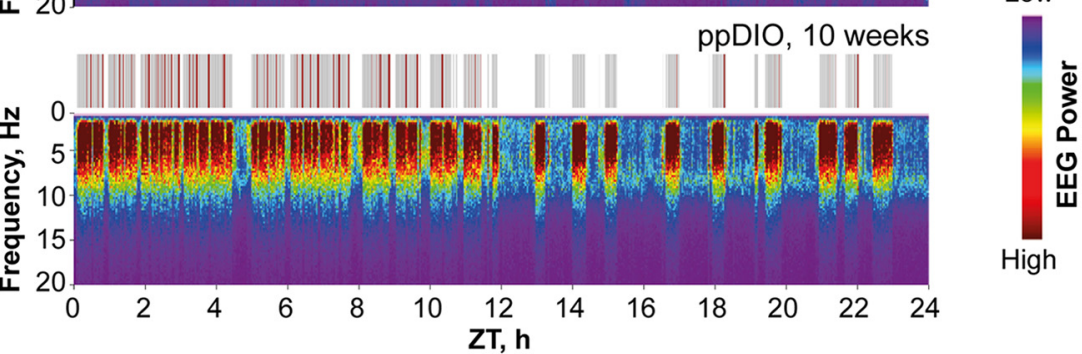

High

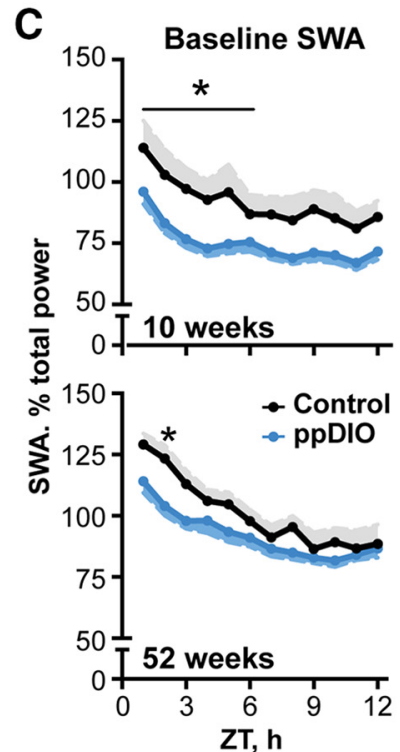

D SWA relative to baseline

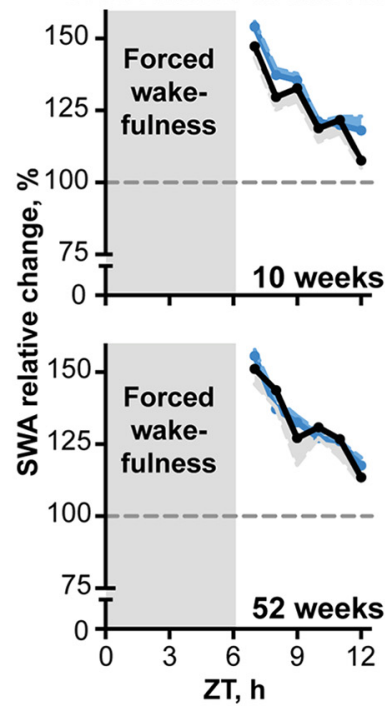

Figure 2. Comparison of changes in sleep architecture and homeostasis in control mice and mice with a ppDIO history. $A$, Number ( \pm SEM) of transitions from NREM sleep to wakefulness (left) and from wakefulness to NREM sleep (right) in 10-week-old (top, ppDI0: $n=17$; control: $n=11$ ) and 52-week-old (bottom; ppDI0: $n=10$; control: $n=11) \mathrm{ppDI0}$ and control mice during $6 \mathrm{~h}$ bins. At 10 weeks of age, ppDI0 mice displayed significantly more frequent transitions compared with control mice $(p<0.01)$, indicative of impaired sleep (Figure legend continues.) 
of SWA during NREM sleep. SWA, which peaks at the onset of sleep and decreases as sleep progresses, provides an index of sleep depth and serves as an objective indicator of sleep quality (Borbély et al., 1989). As shown in representative EEG power spectrograms (Fig. $2 B$ ), the power density within the lower-frequency bands $(\sim 0.5-8 \mathrm{~Hz})$ during NREM sleep bouts was weaker in mice that had been exposed to ppDIO compared with age-matched control animals. Indeed, markedly reduced SWA was observed in ppDIO mice from as early as 10 weeks of age (Fig. 2C, top; diet effect: $F_{(1,24)}=4.869, p<0.05,2$-way ANOVA). Those signs of impaired sleep quality were evident for at least 42 weeks after termination of the ppDIO paradigm when mice were 52 weeks of age (Fig. $2 C$, bottom; diet-time interaction: $F_{(11,176)}=1.895, p<$ $0.05,2$-way ANOVA), being most pronounced at the onset of the resting phase (ZT 2, $p<0.05$, Sidak's post hoc test).

We next investigated whether ppDIO has a detrimental impact upon sleep homeostasis during recovery from sleep deprivation ( $6 \mathrm{~h}$ of forced wakefulness during the resting phase). Sleep deprivation similarly increased SWA (Fig. 2D) and the amount of rebound sleep NREM and REM sleep time in both ppDIO and control mice (data not shown). The magnitude of "catch-up" sleep and the relative change in SWA after sleep deprivation did not differ significantly between peripubertal (10-week-old) and adult (52-week-old) ppDIO versus control mice (data not shown and Fig. 2D); these data indicate that homeostatic sleep pressure is not influenced by ppDIO.

\section{Hypothalamic correlates of ppDIO-associated changes in sleep}

Given the coincidence in the timing of BW gain and altered sleep patterns (increased amount of nocturnal sleep and decreased sleep quality) in ppDIO mice, we next investigated whether changes in the activity of the LH might be responsible for the impact of ppDIO on feeding and sleep. It is pertinent to note here that the LH serves as an integratory hub for both behaviors (Bonnavion et al., 2016). Briefly, hunger and satiety signals are chiefly relayed to the LH from the arcuate nucleus (Arc) (Elias et al., 1998; Schwartz et al., 2000) and feeding is ultimately stimulated after activation of orexin-producing, melanin-concentrating hormone $(\mathrm{MCH})$-producing, and GABA-producing neurons in the LH (Qu et al., 1996; Lubkin and Stricker-Krongrad, 1998; Jennings et al., 2013). Moreover, whereas LH orexin and GABA have been shown to facilitate wakefulness (Adamantidis et al., 2007; Herrera et al., 2016), MCH is known to promote NREM and REM sleep (Jego et al., 2013; Konadhode et al., 2013). At ZT 8 , orexin mRNA levels in the LH did not differ between young (10-week-old) and adult (52-week-old) ppDIO mice (Fig. $3 A$,

\footnotetext{
(Figure legend continued.) stability; such a difference was not detected in mice aged 52 weeks (diet-age-time interaction: NREM $\rightarrow$ WAKE transitions: $F_{(1,46)}=9.266, p<0.01$; WAKE $\rightarrow$ NREM transitions: $\left.F_{(1,46)}=9.599, p<0.01\right) . B$, Exemplary spectrograms with corresponding hypnograms of a 10-week-old control (top) and ppDI0 mouse (bottom) across a $24 \mathrm{~h}$ baseline recording. Compared with controls, ppDIO mice displayed lower intensity of EEG power in the lower-frequency bands during NREM sleep. $\boldsymbol{C}, \boldsymbol{D}$, Hourly changes in SWA during NREM sleep under baseline conditions (percentage \pm SEM; left; 10-week-old ppDI0: $n=17 ; 10$-week-old control: $n=9 ; 52$-week-old ppDI0: $n=7 ; 52$-week-old control: $n=7 ; \boldsymbol{C}$ ) and SWA responses to sleep deprivation through forced wakefulness (relative to the baseline, $\% \pm \mathrm{SEM}$ ) in 10 week-old ( $\boldsymbol{D}$, top; ppDI0: $n=10$; control: $n=4$ ) and 52-week-old ( $\boldsymbol{D}$, bottom; ppDI0: $n=7$; control: $n=7$ ) mice. As compared with baseline SWA (a marker of sleep depth) in controls, SWA was significantly lower in 10-week-old $(p<0.05)$ and 52-week-old ppDI0 mice $(p<0.05)$. However, homeostatic sleep pressure, tested here by forced waking, was accumulated to a similar extent in ppDI0 and control mice. ${ }^{*} p<0.05$.
}

left). However, there was an age-related reduction in the LH content of orexin (Fig. 3A, middle, age effect: $F_{(1,35)}=13.02, p<$ $0.01,2$-way ANOVA), a phenomenon that was more pronounced in control animals $(p<0.01$, Sidak's post hoc test). Neither ppDIO nor age influenced mRNA expression of glutamic acid decarboxylase 67 (GAD67), the rate-limiting enzyme in GABA biosynthesis [10-week-old mice, $0.41 \pm 0.02$ (control) vs $0.41 \pm$ $0.01 \mathrm{nCi} / \mathrm{mg}$ (ppDIO); 52-week-old mice, $0.39 \pm 0.02$ (control) vs $0.39 \pm 0.01 \mathrm{nCi} / \mathrm{mg}$ (ppDIO)] or MCH mRNA levels (Fig. $3 A$, right) in the $\mathrm{LH}$.

Because the LH is densely innervated by $5-\mathrm{HT}$ and DA fibers from the DR and ventral tegmental area, respectively, and 5-HT and DA are implicated in the induction of satiety and wakefulness (Hoebel et al., 1989; Schwartz et al., 1989; Dzirasa et al., 2006; Nonogaki, 2012; Ito et al., 2013), we next analyzed 5-HT and DA levels in the LH. Whereas the LH content of DA was not affected by ppDIO exposure [10-week-old mice, $9.35 \pm 1.49$ (control) vs $9.34 \pm 0.99 \mu \mathrm{mol} / \mu \mathrm{g}$ protein (ppDIO); 52-week-old mice, $8.39 \pm 1.27$ (control) vs $7.00 \pm 1.19 \mu \mathrm{mol} / \mu \mathrm{g}$ protein $(\mathrm{ppDIO})]$, that of 5-HT was significantly reduced in ppDIO mice aged 10 and 52 weeks (Fig. $3 B$, left; diet effect: $F_{(1,34)}=10.61, p<0.01$, 2-way ANOVA; Sidak's multiple-comparisons post hoc test: 10week-old controls vs ppDIO mice: $p<0.05$; 52 -week-old control vs ppDIO mice: n.s.). However, the DR content of 5-HT did not differ between ppDIO and control mice (Fig. 3C, diet effect: $F_{(1,28)}=2.28, p>0.05$; age effect: $\left.F_{(1,28)}=0.63, p>0.05\right)$, suggesting that reduced 5-HTergic tone in the LH contributes to the aberrations in the sleep-wake patterns observed in ppDIO mice.

\section{Rescue of excessive nocturnal sleep in ppDIO mice by peptide $\mathrm{YY}_{3-36}$}

Given that the satiety-inducing effects of 5-HT in the LH are most likely modulated by satiety signals from the periphery (Elias et al., 1999), we hypothesized that ppDIO may interfere with the magnitude or efficacy of the latter. To test this, we mimicked satiety by injection of the potent and rapidly acting satiety peptide $\mathrm{PYY}_{3-36}$ (60 $\mu \mathrm{g} / \mathrm{kg}$, i.p.) (Batterham et al., 2002, 2003; Karra et al., 2009) at ZT 12 (Fig. 3B, right) and measured the levels of 5-HT and its metabolite, 5-HIAA, and DA and its metabolites, DOPAC, HVA, and 3-MT, in the LH of control and ppDIO mice $1 \mathrm{~h}$ after injecting $\mathrm{PYY}_{3-36}$. Whereas $\mathrm{PYY}_{3-36}$ produced only a tendential increase in DA turnover (data not shown), the peptide significantly increased 5-HT turnover in the LH (Fig. 3B, right; treatment effect: $F_{(1,26)}=5.609, p<0.05,2$-way ANOVA) of ppDIO mice ( $p<0.05$, Sidak's post hoc test), compared with controls.

Strikingly, the acute application of $\mathrm{PYY}_{3-36}$ reversed the sleep impairments observed in ppDIO mice (Fig. 3D). Specifically, $\mathrm{PYY}_{3-36}$ increased NREM sleep time in control mice during the first hour after injection independently of age (treatment effect in controls: $F_{(1,17)}=9.792, p<0.01,2$-way ANOVA; Sidak's post hoc test: 10-week-old controls: n.s., 52-week-old controls: $p<$ 0.05); in contrast, $\mathrm{PYY}_{3-36}$ reduced NREM sleep time in ppDIO mice (Fig. $3 D$; treatment effect in ppDIO mice: $F_{(1,15)}=12.75$, $p<0.01,2$-way ANOVA; Sidak's post hoc test: 10-week-old ppDIO mice: $p<0.05$, 52-week-old ppDIO mice: n.s.). Therefore, dietary history (standard chow vs ppDIO, diet-treatment interaction: $F_{(3,32)}=7.309, p<0.01,2$-way ANOVA) clearly plays a role in determining sleep duration. Further, $\mathrm{PYY}_{3-36}$ reversed the aberrant distribution of NREM sleep in adult animals that had experienced the ppDIO paradigm; however, this single treatment did not elicit prolonged effects on sleep quality (SWA and statetransition frequency) during the subsequent light period. 


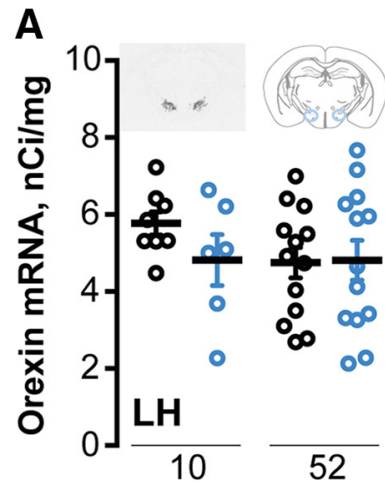

Age, weeks

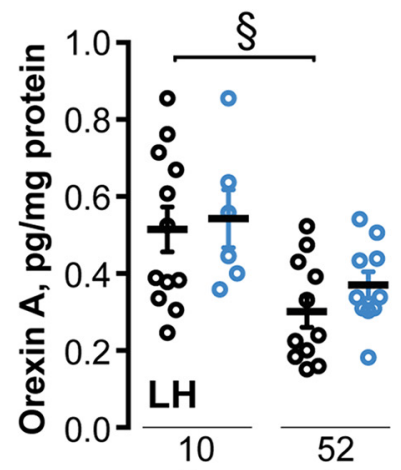

Age, weeks

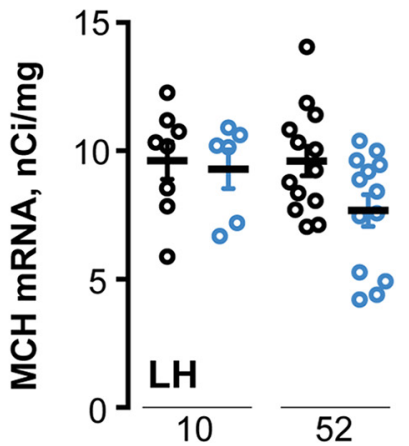

Age, weeks

- Control o ppDIO

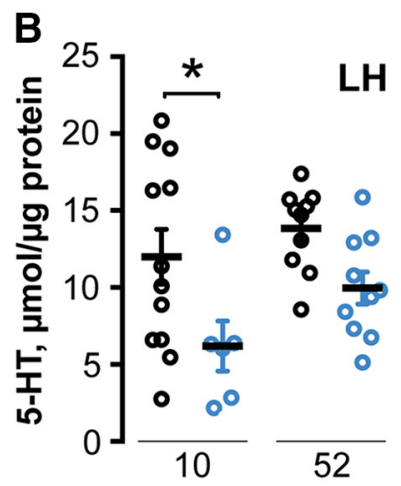

Age, weeks

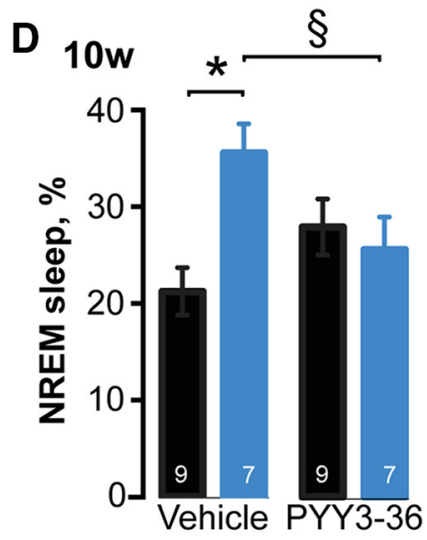

Treatment
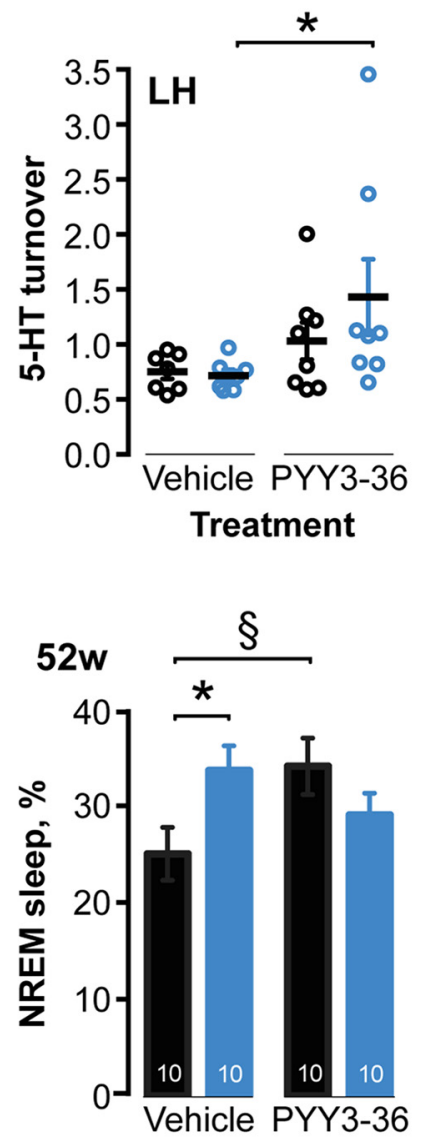

Treatment
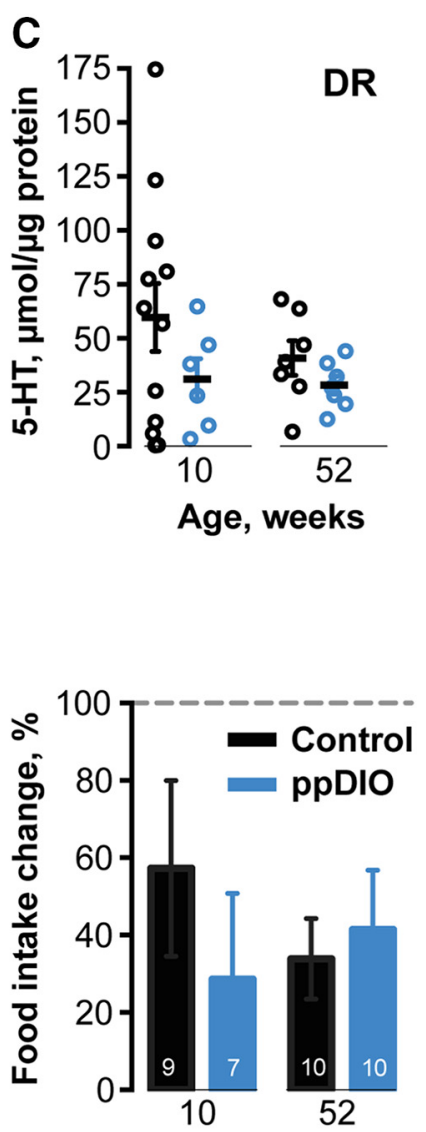

Age, weeks

Figure 3. Reduced hypothalamic 5-HT levels in ppDI0 mice are rescued by PYY3-36 treatment. $A$, Orexin (left) and MCH (right) mRNA and orexin A peptide (middle) levels in the LH of ppDI0 and control mice aged 10 or 52 weeks. Inset (left) is an image of a brain section from a ppDI0 mouse showing in situ hybridization signal for orexin mRNA and the corresponding anatomical reference image (adapted from Paxinos and Franklin, 2001). B, Comparison of 5-HT contents in the LH of ppDI0 and control mice (left). The content of 5 -HT in the LH was significantly reduced in ppDI0-exposed animals $(p<0.05)$. An acute injection of PYY ${ }_{3-36}$ enhanced 5-HTergic tone (5-HT turnover) in the LH of 10-week-old ppDIO mice (middle, $\left.p<0.05\right)$. C, 5-HT contents in the DR of ppDI0 and control mice. Age and diet did not have any significant effect on this measure. $\boldsymbol{D}$, Treatment with $\mathrm{PYY}_{3-36}$ rectified the altered nocturnal sleep patterns for at least $1 \mathrm{~h}$ in $\mathrm{ppDI0}$ mice $(p<0.05)$; data are shown as mean percentage \pm SEM in 10-week-old (left) and 52-week-old (middle) ppDI0 and control mice. Treatment with PYY ${ }_{3-36}$ resulted in a significant reduction of food intake in all experimental groups (right). The dashed line (100\%) represents the amount of food consumed by vehicle-treated ppDI0 and control mice; measurements were made at $1 \mathrm{~h}$ after injection of PYY ${ }_{3-36}$ or vehicle. Numbers of animals in each group are indicated in the bars. ${ }^{*} p<0.05$ between diet groups, $\$ p<0.05$ between age groups.

\section{Discussion}

Neural circuits undergo continuous remodeling under the influence of inherent developmental programs and external environmental stimuli. Reorganization reaches a peak during puberty, with recent research suggesting that peripubertal experiences can determine lifetime behavior and health trajectories (Blakemore,
2012). Sleep, a complex behavior regulated through intricate interactions among different brain areas, neurotransmitters, neuropeptides, and metabolic signals and modulated by a variety of external cues and Zeitgebers, plays an essential role in maintaining physiological and behavioral homeostasis (Roenneberg and Merrow, 2007; Saper et al., 2010; Shukla and Basheer, 2016). 

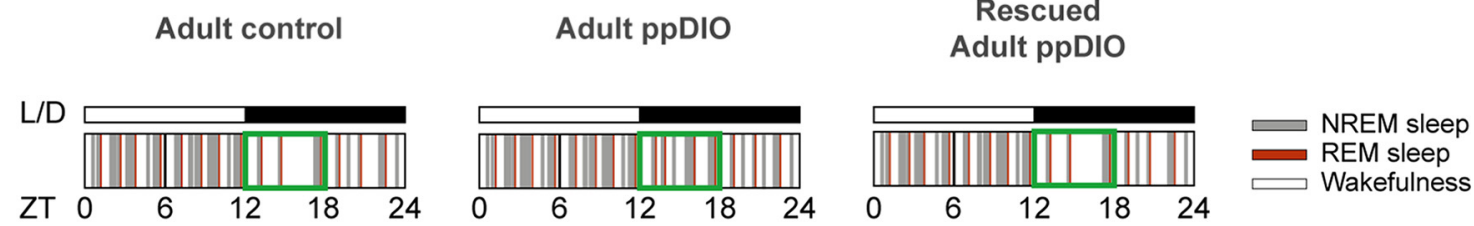

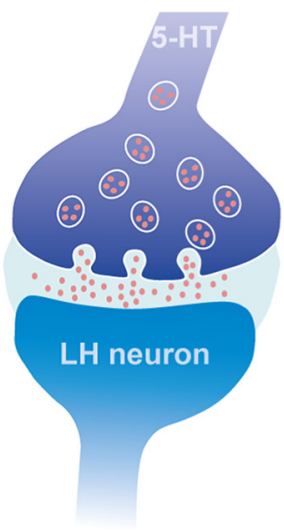

Normometabolism Normal BW

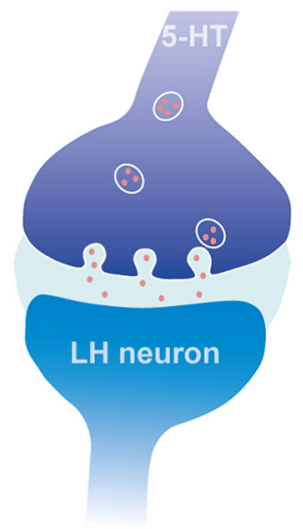

Disrupted metabolism Elevated BW

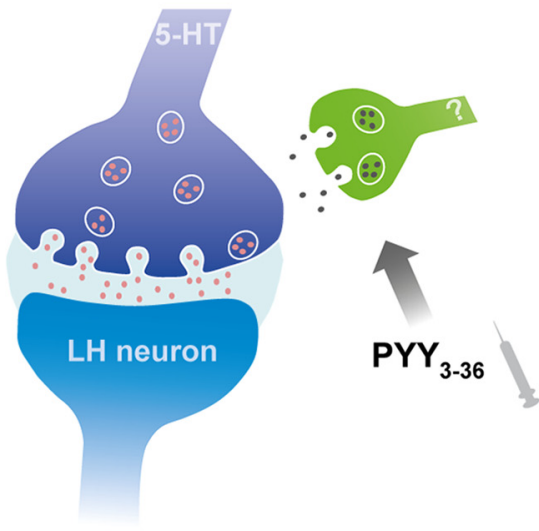

Normometabolism Elevated BW

Figure 4. Schematic representation of how restoration of 5-HTergic tone in the LH by peripherally administered PYY ${ }_{3-36}$ reverses the detrimental effects of ppDI0 on sleep-wake behavior. Sample hypnograms (top) and hypothetical representations of 5-HT neurotransmission at synaptic terminals in the LH (bottom). Left, Normal sleep-wake patterns depend on adequate 5-HTergic innervation of $\mathrm{LH}$ neurons involved in the regulation of feeding and energy metabolism as well as sleep; among others, orexin neurons are a likely target of 5 - $\mathrm{HT}$ originating in neurons located in the dorsal raphe. Middle, Exposure to ppDIO results in persistently blunted 5-HTergic stimulation of the LH and increased amount of inappropriately timed sleep; that is, reduced wakefulness during the normal active phase, especially during the first half of the dark period (green frame). Right, Exogenous (peripheral) administration of PYY ${ }_{3-36}$ to mimic a state of satiety delivers 5 -HT rapidly to the LH

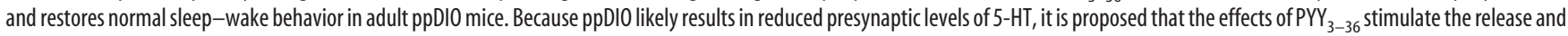
reuptake of 5-HT in the $\mathrm{LH}$. The effect of $\mathrm{PYY}_{3-36}$ on $5-\mathrm{HT}$ levels in the $\mathrm{LH}$ is likely conveyed by intermediary neurons (identity presently unknown) rather than by diffusion of PYY ${ }_{3-36}$ to the $\mathrm{LH}_{\text {, as }}$ indicated by the green terminal.

The present study demonstrates that transient exposure to an obesogenic diet during peripuberty (ppDIO) triggers profound and long-lasting alterations in sleep depth, duration, and distribution. Similar aberrations in sleep have been reported previously after DIO in adult rodents (Jenkins et al., 2006; Guan et al., 2008). However, whereas the disturbed sleep phenotype that follows DIO during adulthood is reversible by induction of weight loss (e.g., through re-exposure to standard diet; Guan et al., 2008; Perron et al., 2015), the present results show that the effects of transient DIO during the peripubertal period on $\mathrm{BW}$ and sleep disturbances persist throughout life. Analysis revealed that ppDIO impairs sleep quality by increasing sleep fragmentation and lowering SWA followed by a compensatory increase in sleep during the nocturnal (active) phase. The sleep phenotype of ppDIO mice resembles that seen in obese humans who report daytime sleepiness and the frequent occurrence of arousal during normal sleep time (Vgontzas et al., 2008); therefore, these observations may have wider implications because sleep quality is known to affect cognitive and affective functions (Steiger and Kimura, 2010; Roth, 2015).

Our search for mechanisms that might explain the impaired sleep phenotype expressed by ppDIO mice was based on the postulate that ppDIO induces robust rewiring of neuronal circuits that regulate and link metabolism and sleep. We initially considered the orexinergic system as a likely target of ppDIO, because orexin neurons in the LH innervate brain regions involved in the regulation of both arousal and feeding (Sakurai, 2005; Adamantidis and de Lecea, 2008). Previous studies suggested an inverse relationship between orexin mRNA expression and peptide levels in the LH and the amount of NREM sleep in adult DIO mice (Kohsaka et al., 2007; Tanno et al., 2013). Because we did not detect altered orexin expression in ppDIO mice, we next asked whether ppDIO modulates $\mathrm{MCH}$ and/or GABA expression in the $\mathrm{LH}$. The LH is known to contain both $\mathrm{MCH}$ and GABA neurons, which exert reciprocal control over metabolism and sleep. Specifically, enhanced GABA activity in the LH induces arousal from NREM sleep and elicits feeding (Jennings et al., 2015; Herrera et al., 2016), whereas activation of MCH neurons in the LH increases meal size and counters the wake-promoting actions of orexin (Kowalski et al., 2004; Jego et al., 2013; Konadhode et al., 2013; Apergis-Schoute et al., 2015). However, lack of altered expression of MCH and GAD67 (which catalyzes the decarboxylation of glutamate to GABA) mRNA in ppDIO mice suggested that neuromodulators other than MCH/GAD67 might be responsible for the impaired sleep displayed by these animals. In addition to MCH/GAD67 and orexin, the LH contains a separate population of GABAergic [vesicular GABA transporter (Vgat)expressing] neurons, which support the actions of orexin by producing arousal and facilitating feeding (Jennings et al., 2015; Herrera et al., 2016). Moreover, glutamatergic and dynorphin-expressing neurons present in the LH are reported to oppose orexinergic function in reward-related tasks (Muschamp et al., 2014; Stamatakis et al., 2016). Although the role of these latter neurons in sleep-wake regulation has yet to be defined, their possible involvement in obesityassociated sleep disturbances cannot be excluded.

Because 5-HT is suggested to dissociate feeding cues from wakefulness (Sakurai, 2005; Nonogaki, 2012), we subsequently 
investigated whether ppDIO modulates the amount of 5-HT reaching the LH from the DR nucleus. Whereas increased 5-HTergic tone is generally associated with wakefulness, it also induces satiety specifically by acting on the LH (Hoebel et al., 1989; Le Feuvre et al., 1991; Nonogaki, 2012; Ito et al., 2013). Although similar 5-HT levels were found in the DR of control and ppDIO mice, we observed markedly lower amounts of 5-HT in the LH of ppDIO versus control animals. Because 5-HT is a potent signal of satiety (Schwartz et al., 1989; Le Feuvre et al., 1991; Kumar et al., 2007; Burke et al., 2014), the reduced 5-HTergic tone observed in the LH of both peripubertal and adult ppDIO mice implies that ppDIO impairs the transduction of satiety signals, leading to persistent obesity. Further, given that 5-HT promotes wakefulness (Ito et al., 2013), the reduced 5-HT-mediated signaling of satiety may plausibly be linked to the sleep phenotype of ppDIO animals.

Peripheral cues of satiety are centrally integrated into the regulatory mechanisms responsible for sleep-wake behavior (Shukla and Basheer, 2016). Because systemic levels of the gut-derived satiety peptide $\mathrm{PYY}_{3-36}$ are reduced in obese humans (Batterham et al., 2003; Karra et al., 2009), we hypothesized that mimicking a state of satiety with exogenous $\mathrm{PYY}_{3-36}$ would restore normal sleep-wake profiles in ppDIO mice. In agreement with previous findings in diet-induced obese adult rats (Reidelberger et al., 2008), acute peripheral administration of $\mathrm{PYY}_{3-36}$ was found to similarly suppress feeding in control and ppDIO mice. As predicted (Akanmu et al., 2006), $\mathrm{PYY}_{3-36}$ promoted sleep time in control animals. In contrast, injection with the same dose of $\mathrm{PYY}_{3-36}$ reduced the abnormally enhanced sleep displayed by ppDIO mice during the active phase of the light/dark cycle. Interestingly, the pharmacological intervention was accompanied by a contemporaneous increase in 5-HT turnover in the LH. Based on this result, we propose that $\mathrm{PYY}_{3-36}$ rescues the sleep impairment induced by ppDIO by augmenting 5-HT tone in the LH (see Fig. 4 for a hypothetical model). At present, the mechanism by which PYY $3-36$ affects 5-HT signaling in the LH is unknown. However, because $\mathrm{PYY}_{3-36}$ can cross the blood-brain barrier and act directly on Arc neurons (Nonaka et al., 2003), it is plausible that $\mathrm{PYY}_{3-36}$ signals are polysynaptically conveyed to the LH (Blevins et al., 2008) (Fig. 4, green terminal). Indeed, $\mathrm{PYY}_{3-36}$ likely suppresses the release of the orexigenic neuropeptide Y (NPY) after binding to Y2 receptors in the Arc (Grandt et al., 1992); note that NPY neurons in the Arc project to the LH (Elias et al., 1999) and that intra-LH injections of NPY were found previously to blunt 5-HT signaling locally (Shimizu and Bray, 1989). Pending the results of experiments to unravel the complex pathways involved, we presently suggest that $\mathrm{PYY}_{3-36}$-induced increases in 5-HT release in the LH results from the relief of NPY inhibition of 5-HT activity. Although it is also plausible that $\mathrm{PYY}_{3-36}$ modulates the activity of 5-HT neurons directly by binding to Y2 receptors in the DR (Dumont et al., 1996; Nectow et al., 2017), the latter mechanism seems unlikely because the current study found no enhancement of DR 5-HT turnover by peripherally administered PYY ${ }_{3-36}$.

An additional important finding in this study was that PYY $_{3-36}$ reversed the "excessive daytime sleepiness" displayed by ppDIO mice, suggesting that the therapeutic potential of $\mathrm{PYY}_{3-36}$ to reset diet-induced sleep disturbances may be worthy of exploration. Furthermore, our results demonstrate that the window of time for interventions aimed at reversing the detrimental effects of ppDIO is wide, possibly extending over the whole lifespan.

In summary, this study shows that transient DIO during peripubertal development predestinates mice for lifetime obesity and dysregulated sleep-wake behavior by affecting the 5-HT- mediated relay of peripheral signals of satiety to the LH. This work also demonstrates that pharmacological mimicry of satiety by an acute injection of $\mathrm{PYY}_{3-36}$ can reverse the neurochemical imbalance induced by peripubertal obesity and re-establish normophysiological sleep-wake cycles. Interestingly, the pharmacological intervention is efficient even if introduced months after the onset of adult obesity.

\section{References}

Adamantidis A, de Lecea L (2008) Sleep and metabolism: shared circuits, new connections. Trends Endocrinol Metab 19:362-370. CrossRef Medline

Adamantidis AR, Zhang F, Aravanis AM, Deisseroth K, de Lecea L (2007) Neural substrates of awakening probed with optogenetic control of hypocretin neurons. Nature 450:420-424. CrossRef Medline

Akanmu MA, Ukponmwan OE, Katayama Y, Honda K (2006) Neuropeptide-Y Y2-receptor agonist, PYY3-36 promotes non-rapid eye movement sleep in rat. Neurosci Res 54:165-170. CrossRef Medline

Alfaradhi MZ, Ozanne SE (2011) Developmental programming in response to maternal overnutrition. Front Genet 2:27. CrossRef Medline

Anderzhanova EA, Bächli H, Buneeva OA, Narkevich VB, Medvedev AE, Thoeringer CK, Wotjak CT, Kudrin VS (2013) Strain differences in profiles of dopaminergic neurotransmission in the prefrontal cortex of the BALB/C vs C57BL/6 mice: consequences of stress and afobazole. Eur J Pharmacol 708:95-104. CrossRef Medline

Apergis-Schoute J, Iordanidou P, Faure C, Jego S, Schöne C, Aitta-Aho T, Adamantidis A, Burdakov D (2015) Optogenetic evidence for inhibitory signaling from orexin to $\mathrm{MCH}$ neurons via local microcircuits. J Neurosci 35:5435-5441. CrossRef Medline

Balakumar P, Maung-U K, Jagadeesh G (2016) Prevalence and prevention of cardiovascular disease and diabetes mellitus. Pharmacol Res 113:600609. CrossRef Medline

Batterham RL, Cowley MA, Small CJ, Herzog H, Cohen MA, Dakin CL, Wren AM, Brynes AE, Low MJ, Ghatei MA, Cone RD, Bloom SR (2002) Gut hormone PYY(3-36) physiologically inhibits food intake. Nature 418: 650-654. CrossRef Medline

Batterham RL, Cohen MA, Ellis SM, Le Roux CW, Withers DJ, Frost GS, Ghatei MA, Bloom SR (2003) Inhibition of food intake in obese subjects by peptide YY3-36. N Engl J Med 349:941-948. CrossRef Medline

Blakemore SJ (2012) Imaging brain development: the adolescent brain. Neuroimage 61:397-406. CrossRef Medline

Blevins JE, Chelikani PK, Haver AC, Reidelberger RD (2008) PYY(3-36) induces Fos in the arcuate nucleus and in both catecholaminergic and non-catecholaminergic neurons in the nucleus tractus solitarius of rats. Peptides 29:112-119. CrossRef Medline

Bonnavion P, Mickelsen LE, Fujita A, de Lecea L, Jackson AC (2016) Hubs and spokes of the lateral hypothalamus: cell types, circuits and behaviour. J Physiol 594:6443-6462. CrossRef Medline

Borbély AA (1977) Sleep in the rat during food deprivation and subsequent restitution of food. Brain Res 124:457-471. CrossRef Medline

Borbély AA, Achermann P, Trachsel L, Tobler I (1989) Sleep initiation and initial sleep intensity: interactions of homeostatic and circadian mechanisms. J Biol Rhythms 4:149-160. Medline

Burke LK, Doslikova B, D’Agostino G, Garfield AS, Farooq G, Burdakov D, Low MJ, Rubinstein M, Evans ML, Billups B, Heisler LK (2014) 5-HT obesity medication efficacy via POMC activation is maintained during aging. Endocrinology 155:3732-3738. CrossRef Medline

Challet E (2013) Circadian clocks, food intake, and metabolism. Prog Mol Biol Transl Sci 119:105-135. CrossRef Medline

Chaput JP, Dutil C (2016) Lack of sleep as a contributor to obesity in adolescents: impacts on eating and activity behaviors. Int J Behav Nutr Phys Act 13:103. CrossRef Medline

Chowdhury S, Yamanaka A (2016) Optogenetic activation of serotonergic terminals facilitates GABAergic inhibitory input to orexin/hypocretin neurons. Sci Rep 6:36039. CrossRef Medline

Dresler M, Spoormaker VI, Beitinger P, Czisch M, Kimura M, Steiger A, Holsboer F (2014) Neuroscience-driven discovery and development of sleep therapeutics. Pharmacol Ther 141:300-334. CrossRef Medline

Dumont Y, Fournier A, St-Pierre S, Quirion R (1996) Autoradiographic distribution of [125I][Leu31, Pro34]PYY and [125I]PYY3-36 binding sites in the rat brain evaluated with two newly developed Y1 and Y2 receptor radioligands Synapse 22:139-158. CrossRef 
Dzirasa K, Ribeiro S, Costa R, Santos LM, Lin SC, Grosmark A, Sotnikova TD, Gainetdinov RR, Caron MG, Nicolelis MAL (2006) Dopaminergic control of sleep-wake states. J Neurosci 26:10577-10589. CrossRef Medline

Elias CF, Saper CB, Maratos-Flier E, Tritos NA, Lee C, Kelly J, Tatro JB, Hoffman GE, Ollmann MM, Barsh GS, Sakurai T, Yanagisawa M, Elmquist JK (1998) Chemically defined projections linking the mediobasal hypothalamus and the lateral hypothalamic area. J Comp Neurol 402:442-459. CrossRef Medline

Elias CF, Aschkenasi C, Lee C, Kelly J, Ahima RS, Bjorbaek C, Flier JS, Saper CB, Elmquist JK (1999) Leptin differentially regulates NPY and POMC neurons projecting to the lateral hypothalamic area. Neuron 23:775-786. CrossRef Medline

Grandt D, Teyssen S, Schimiczek M, Reeve JR Jr, Feth F, Rascher W, Hirche H, Singer MV, Layer P, Goebell H (1992) Novel generation of hormone receptor specificity by amino terminal processing of peptide YY. Biochem Biophys Res Commun 186:1299-1306. CrossRef Medline

Guan Z, Vgontzas AN, Bixler EO, Fang J (2008) Sleep is increased by weight gain and decreased by weight loss in mice. Sleep 31:627-633. CrossRef Medline

Hagenauer MH, Lee TM (2013) Adolescent sleep patterns in humans and laboratory animals. Horm Behav 64:270-279. CrossRef Medline

Havekes R, Meerlo P, Abel T (2015) Animal studies on the role of sleep in memory: from behavioral performance to molecular mechanisms. Curr Top Behav Neurosci 25:183-206. CrossRef Medline

Herrera CG, Cadavieco MC, Jego S, Ponomarenko A, Korotkova T, Adamantidis A (2016) Hypothalamic feedforward inhibition of thalamocortical network controls arousal and consciousness. Nat Neurosci 19:290-298. CrossRef Medline

Hoebel BG, Hernandez L, Schwartz DH, Mark GP, Hunter GA (1989) Microdialysis studies of brain norepinephrine, serotonin, and dopamine release during ingestive behavior: theoretical and clinical implications. Ann N Y Acad Sci 575:171-191; discussion 192-193. CrossRef Medline

Iñiguez SD, Riggs LM, Nieto SJ, Wright KN, Zamora NN, Cruz B, Zavala AR, Robison AJ, Mazei-Robison MS (2015) Fluoxetine exposure during adolescence increases preference for cocaine in adulthood. Sci Rep 5:15009. CrossRef Medline

Ito H, Yanase M, Yamashita A, Kitabatake C, Hamada A, Suhara Y, Narita M, Ikegami D, Sakai H, Yamazaki M, Narita M (2013) Analysis of sleep disorders under pain using an optogenetic tool: possible involvement of the activation of dorsal raphe nucleus-serotonergic neurons. Mol Brain 6:59. CrossRef Medline

Jakubcakova V, Flachskamm C, Deussing JM, Kimura M (2011) Deficiency of corticotropin-releasing hormone type-2 receptor alters sleep responses to bacterial lipopolysaccharide in mice. Brain Behav Immun 25:16261636. CrossRef Medline

Jego S, Glasgow SD, Herrera CG, Ekstrand M, Reed SJ, Boyce R, Friedman J, Burdakov D, Adamantidis AR (2013) Optogenetic identification of a rapid eye movement sleep modulatory circuit in the hypothalamus. Nat Neurosci 16:1637-1643. CrossRef Medline

Jenkins JB, Omori T, Guan Z, Vgontzas AN, Bixler EO, Fang J (2006) Sleep is increased in mice with obesity induced by high-fat food. Physiol Behav 87:255-262. CrossRef Medline

Jennings JH, Rizzi G, Stamatakis AM, Ung RL, Stuber GD (2013) The inhibitory circuit architecture of the lateral hypothalamus orchestrates feeding. Science 341:1517-1521. CrossRef Medline

Jennings JH, Ung RL, Resendez SL, Stamatakis AM, Taylor JG, Huang J, Veleta K, Kantak PA, Aita M, Shilling-Scrivo K, Ramakrishnan C, Deisseroth K, Otte S, Stuber GD (2015) Visualizing hypothalamic network dynamics for appetitive and consummatory behaviors. Cell 160:516-527. CrossRef Medline

Karra E, Chandarana K, Batterham RL (2009) The role of peptide YY in appetite regulation and obesity. J Physiol 587:19-25. CrossRef Medline

Kelsey MM, Zaepfel A, Bjornstad P, Nadeau KJ (2014) Age-related consequences of childhood obesity. Gerontology 60:222-228. CrossRef Medline

Kimura M, Müller-Preuss P, Lu A, Wiesner E, Flachskamm C, Wurst W, Holsboer F, Deussing JM (2010) Conditional corticotropin-releasing hormone overexpression in the mouse forebrain enhances rapid eye movement sleep. Mol Psychiatry 15:154-165. CrossRef Medline

Kohsaka A, Laposky AD, Ramsey KM, Estrada C, Joshu C, Kobayashi Y, Turek FW, Bass J (2007) High-fat diet disrupts behavioral and molecular circadian rhythms in mice. Cell Metab 6:414-421. CrossRef Medline Konadhode RR, Pelluru D, Blanco-Centurion C, Zayachkivsky A, Liu M,
Uhde T, Glen WB Jr, van den Pol AN, Mulholland PJ, Shiromani PJ (2013) Optogenetic stimulation of MCH neurons increases sleep. J Neurosci 33:10257-10263. CrossRef Medline

Kowalski TJ, Farley C, Cohen-Williams ME, Varty G, Spar BD (2004) Melanin-concentrating hormone-1 receptor antagonism decreases feeding by reducing meal size. Eur J Pharmacol 497:41-47. CrossRef Medline Kumar D, Dedic N, Flachskamm C, Voulé S, Deussing JM, Kimura M (2015) Cacnalc (Cav1.2) modulates electroencephalographic rhythm and rapid eye movement sleep recovery. Sleep 38:1371-1380. CrossRef Medline

Kumar S, Szymusiak R, Bashir T, Rai S, McGinty D, Alam MN (2007) Effects of serotonin on perifornical-lateral hypothalamic area neurons in rat. Eur J Neurosci 25:201-212. CrossRef Medline

Le Feuvre RA, Aisenthal L, Rothwell NJ (1991) Involvement of corticotrophin releasing factor (CRF) in the thermogenic and anorexic actions of serotonin (5-HT) and related compounds. Brain Res 555:245-250. CrossRef Medline

Le Moal M, Simon H (1991) Mesocorticolimbic dopaminergic network: functional and regulatory roles. Physiol Rev 71:155-234. Medline

Lowry OH, Rosebrough NJ, Farr AL, Randall RJ (1951) Protein measurement with the Folin phenol reagent. J Biol Chem 193:265-275. Medline

Lubkin M, Stricker-Krongrad A (1998) Independent feeding and metabolic actions of orexins in mice. Biochem Biophys Res Commun 253:241-245. CrossRef Medline

Markwald RR, Melanson EL, Smith MR, Higgins J, Perreault L, Eckel RH, Wright KP Jr (2013) Impact of insufficient sleep on total daily energy expenditure, food intake, and weight gain. Proc Natl Acad Sci U S A 110: 5695-5700. CrossRef Medline

Muschamp JW, Hollander JA, Thompson JL, Voren G, Hassinger LC, Onvani S, Kamenecka TM, Borgland SL, Kenny PJ, Carlezon WA Jr (2014) Hypocretin (orexin) facilitates reward by attenuating the antireward effects of its cotransmitter dynorphin in ventral tegmental area. Proc Natl Acad Sci U S A 111:E1648-E1655. CrossRef Medline

Nectow AR, Schneeberger M, Zhang H, Field BC, Renier N, Azevedo E, Patel B, Liang Y, Mitra S, Tessier-Lavigne M, Han MH, Friedman JM (2017) Identification of a brainstem circuit controlling feeding. Cell 170:429442.e11. CrossRef Medline

Nelson AB, Faraguna U, Zoltan JT, Tononi G, Cirelli C (2013) Sleep patterns and homeostatic mechanisms in adolescent mice. Brain Sci 3:318 343. CrossRef Medline

Nonaka N, Shioda S, Niehoff ML, Banks WA (2003) Characterization of blood-brain barrier permeability to PYY3-36 in the mouse. J Pharmacol Exp Ther 306:948-953. CrossRef Medline

Nonogaki K (2012) Serotonin conflict in sleep-feeding. Vitam Horm 89: 223-239. CrossRef Medline

Palkovits M (1973) Isolated removal of hypothalamic or other brain nuclei of the rat. Brain Res 59:449-450. CrossRef Medline

Patchev AV, Fischer D, Wolf SS, Herkenham M, Götz F, Gehin M, Chambon P, Patchev VK, Almeida OF (2007) Insidious adrenocortical insufficiency underlies neuroendocrine dysregulation in TIF-2 deficient mice. FASEB J 21:231-238. Medline

Patchev AV, Rodrigues AJ, Sousa N, Spengler D, Almeida OFX (2014) The future is now: early life events preset adult behaviour. Acta Physiol (Oxf) 210:46-57. CrossRef Medline

Paxinos G, Franklin KB (2001) The mouse brain in stereotaxic coordinates, Ed 2. San Diego: Academic.

Perron IJ, Pack AI, Veasey S (2015) Diet/energy balance affect sleep and wakefulness independent of body weight. Sleep 38:1893-1903. CrossRef Medline

Qu D, Ludwig DS, Gammeltoft S, Piper M, Pelleymounter MA, Cullen MJ, Mathes WF, Przypek R, Kanarek R, Maratos-Flier E (1996) A role for melanin-concentrating hormone in the central regulation of feeding behaviour. Nature 380:243-247. CrossRef Medline

Reidelberger RD, Haver AC, Chelikani PK, Buescher JL (2008) Effects of different intermittent peptide YY (3-36) dosing strategies on food intake, body weight, and adiposity in diet-induced obese rats. Am J Physiol Regul Integr Comp Physiol 295:R449-R458. CrossRef Medline

Roenneberg T, Merrow M (2007) Entrainment of the human circadian clock. Cold Spring Harb Symp Quant Biol 72:293-299. CrossRef Medline

Romanowski CP, Fenzl T, Flachskamm C, Wurst W, Holsboer F, Deussing JM, Kimura M (2010) Central deficiency of corticotropin-releasing hormone receptor type 1 (CRH-R1) abolishes effects of CRH on NREM but not on REM sleep in mice. Sleep 33:427-436. CrossRef Medline 
Roth T (2015) Effects of excessive daytime sleepiness and fatigue on overall health and cognitive function. J Clin Psychiatry 76:e1145. CrossRef Medline

Sakurai T (2005) Roles of orexin/hypocretin in regulation of sleep/wakefulness and energy homeostasis. Sleep Med Rev 9:231-241. CrossRef Medline

Saper CB, Fuller PM, Pedersen NP, Lu J, Scammell TE (2010) Sleep state switching. Neuron 68:1023-1042. CrossRef Medline

Schwartz DH, McClane S, Hernandez L, Hoebel BG (1989) Feeding increases extracellular serotonin in the lateral hypothalamus of the rat as measured by microdialysis. Brain Res 479:349-354. CrossRef Medline

Schwartz MW, Woods SC, Porte D Jr, Seeley RJ, Baskin DG (2000) Central nervous system control of food intake. Nature 404:661-671. CrossRef Medline

Serdula MK, Ivery D, Coates RJ, Freedman DS, Williamson DF, Byers T (1993) Do obese children become obese adults? A review of the literature. Prev Med 22:167-177. CrossRef Medline

Shimizu H, Bray GA (1989) Effects of neuropeptide Y on norepinephrine and serotonin metabolism in rat hypothalamus in vivo. Brain Res Bull 22:945-950. CrossRef Medline

Shukla C, Basheer R (2016) Metabolic signals in sleep regulation: recent insights. Nat Sci Sleep 8:9-20. CrossRef Medline

Spear LP (2000) The adolescent brain and age-related behavioral manifestations. Neurosci Biobehav Rev 24:417-463. CrossRef Medline

Stamatakis AM, Van Swieten M, Basiri ML, Blair GA, Kantak P, Stuber GD (2016) Lateral hypothalamic area glutamatergic neurons and their projections to the lateral habenula regulate feeding and reward. J Neurosci 36:302-311. CrossRef Medline

Steiger A, Kimura M (2010) Wake and sleep EEG provide biomarkers in depression. J Psychiatr Res 44:242-252. CrossRef Medline
Stuber GD, Wise RA (2016) Lateral hypothalamic circuits for feeding and reward. Nat Neurosci 19:198-205. CrossRef Medline

Tanno S, Terao A, Okamatsu-Ogura Y, Kimura K (2013) Hypothalamic prepro-orexin mRNA level is inversely correlated to the non-rapid eye movement sleep level in high-fat diet-induced obese mice. Obes Res Clin Pract 7:e251-257. CrossRef Medline

Tarokh L, Saletin JM, Carskadon MA (2016) Sleep in adolescence: Physiology, cognition and mental health. Neurosci Biobehav Rev 70:182-188. CrossRef Medline

Tobler I (1995) Is sleep fundamentally different between mammalian species? Behav Brain Res 69:35-41. CrossRef Medline

Vendruscolo LF, Gueye AB, Darnaudéry M, Ahmed SH, Cador M (2010) Sugar overconsumption during adolescence selectively alters motivation and reward function in adult rats. PLoS One 5:e9296. CrossRef Medline

Vgontzas AN, Bixler EO, Chrousos GP, Pejovic S (2008) Obesity and sleep disturbances: meaningful sub-typing of obesity. Arch Physiol Biochem 114:224-236. CrossRef Medline

Wang Y, Carreras A, Lee S, Hakim F, Zhang SX, Nair D, Ye H, Gozal D (2014) Chronic sleep fragmentation promotes obesity in young adult mice. Obesity 22:758-762. CrossRef Medline

Yamanaka A, Beuckmann CT, Willie JT, Hara J, Tsujino N, Mieda M, Tominaga M, Yagami Ki, Sugiyama F, Goto K, Yanagisawa M, Sakurai T (2003a) Hypothalamic orexin neurons regulate arousal according to energy balance in mice. Neuron 38:701-713. CrossRef Medline

Yamanaka A, Muraki Y, Tsujino N, Goto K, Sakurai T (2003b) Regulation of orexin neurons by the monoaminergic and cholinergic systems. Biochem Biophys Res Commun 303:120-129. CrossRef Medline 